\title{
Ethnic party competition beyond the segmented market
}

\author{
Christina Isabel Zuber* \\ Department of Political Science, University of Cologne, Germany
}

\begin{abstract}
The outbidding model of ethnic politics focuses on party competition in an ethnically perfectly segmented electoral market where no party appeals to voters across the ethnic divide. The power sharing model retains this assumption, yet tries to prevent outbidding through moderation inducing institutional design. Empirically, imperfectly segmented electoral markets and variance of ethnic party strategies beyond radical outbidding have been observed. To provide a stepping stone towards a more complete theory of ethnic party competition, this article introduces the notion of nested competition, defined as party competition in an imperfectly segmented market where some but not all parties make offers across ethnic divides and where competition in intra ethnic arenas is nested within an inter ethnic arena of party competition. The notion of nested competition helps explain why ethnic outbidding is not omnipresent in contemporary multi ethnic democracies. A moderate position on the ethnic dimension that appears inauspicious from the perspective of intra ethnic competition can turn into the strategically superior choice once ethnic parties take the whole system of competitive interactions within intra and inter ethnic arenas into account. A case study of nested competition for Hungarian votes in the Vojvodina region of Northern Serbia illustrates the conceptual innovations.
\end{abstract}

Keywords: ethnic party competition; ethnic segmentation; outbidding model;

Vojvodina; Hungarian parties

\section{Introduction}

What explains the presence or absence of ethnic outbidding in electoral competition? Why did the newest ethnic Hungarian party in Slovakia, "Most-Híd", decide to appeal to voters on both sides of the ethnic divide, offering a moderate program of the middle ground, whereas the "Hungarian Civic Party" in Romania decided to outbid the established Hungarian UDMR with more radical, exclusively Hungarian demands? (Bochsler and Szöcsik). Understanding the rationale behind this strategic choice is highly relevant, as the overall outcomes of inter-ethnic peace and democratic stability partly depend on whether moderates or radicals prevail in representing ethnic interests in democracies where ethnic identity categories are politically mobilized. However, as several authors have recently pointed out, the level of inter-communal conflict has figured so prominently in the literature on ethnically divided societies that the various ways in which individuals and organizations compete for support within ethnic groups ${ }^{1}$ has been largely overlooked (Andeweg 529; Caspersen 7 8; Gormley-Heenan and Mac Ginty 43).

A key reason for this scholarly disregard can be found in the fact that the two most prominent theories of ethnic politics have tended to oversimplify the logic of party

*Email: zuberc@uni koeln.de 
competition in societies where ethnicity is politically mobilized. The power sharing model of ethnic politics (Lijphart "Democracy in plural societies"; Sisk; Norris) does not accord a prominent role to party competition at all since it deliberately aims to avoid the dangers ethnic competition is believed to be posing for democratic stability: "the entire "consociational democracy' is a theory of competition avoidance" (Bartolini "Collusion Part II" 40, original hyphenation). By contrast, the outbidding model of ethnic politics (Rabushka and Shepsle; Horowitz part three) is a theory of ethnic party competition. Seeking to maximize votes, ethnic parties are expected to choose radical over moderate strategies in intra-ethnic competition, since in societies where ethnicity is mobilized, voters are assumed to have intransigent, homogeneous group preferences (Rabushka and Shepsle 67; Horowitz 297). The theory focuses on party competition in ethnically segmented markets where polarized competition for radical voters lets outbidding parties prevail.

An emerging line of research in the field of ethnic politics is, however, beginning to treat democratic politics in ethnically plural societies as a story with an open ending. Authors are beginning to acknowledge that ethnic groups cannot be treated as unified actors with homogeneous, radical preferences by default (Birnir; Hale), that ethnic parties' strategic behavior does not always correspond to the logic of ethnic outbidding (Bochsler and Szöcsik; Caspersen; Chandra; Coakley; Mitchell and O'Leary; Zuber), and that different levels of competition can explain variation in outcomes such as the extent of ethnic violence even when holding the institutional power sharing framework constant (Wilkinson).

Since these empirical findings are at odds with conventional theories of ethnic politics, this article connects theories of ethnic politics to theories of party competition to provide a stepping stone towards a more complete theory of ethnic party competition. The aim is to provide new theoretical concepts that can account for empirically observed alternatives to perfect ethnic segmentation and radical, outbidding ethnic parties. Whereas in perfectly segmented markets party competition exists only among parties appealing to voters from the same ethnic group, in imperfectly segmented markets parties compete for votes also across ethnic divides. Drawing inspiration from Tsebelis' famous account of nested games, I introduce the notion of nested competition to describe the latter cases. Nested competition is defined as party competition in an ethnically imperfectly segmented market where some but not all parties make offers across ethnic divides and where ethnic competition within one or several intra-ethnic arenas is nested within an interethnic arena of party competition. Parties can themselves aim to segment or de-segment the market by choosing between exclusive and non-exclusive appeal to an ethnic identity category. Additionally, parties can choose between different policy positions on an ethnic dimension of competition (Protsyk and Garaz; Zuber 3 4). Adding the notion of nested competition to a theory of ethnic party competition can explain why ethnic outbidding is not omnipresent in contemporary multi-ethnic democracies. I will argue that in cases where a moderate position on the ethnic dimension may appear inauspicious from the perspective of intra-ethnic competition, it can turn into the strategically superior choice once ethnic parties take the whole system of competitive interactions within intra- and interethnic arenas into account (in analogy to Tsebelis, 10 11). ${ }^{2}$ Nested competition therefore emphasizes the previously neglected fact that ethnic party elites choose their strategies not only in light of societal preferences (outbidding) and institutional parameters (power sharing), but also in light of the behavior of their competitors.

The article is structured as follows. The next section lays out a general framework of party competition and reconstructs the assumptions of the outbidding model and the power sharing model from this perspective. The third section introduces the notion of nested 
competition and discusses its implications for ethnic parties' strategic choices. The fourth section presents a case study of nested competition for Hungarian votes in the Vojvodina region of Northern Serbia that illustrates how the new concepts can be applied in empirical research. The last section concludes.

\section{Ethnic party competition in the perfectly segmented market}

In order to define a party as an ethnic party, Chandra focuses on the party's programmatic appeal: "an ethnic party appeals to voters as the champion of the interests of one ethnic category or set of categories to the exclusion of others, and makes such an appeal central to its mobilizing strategy. The key aspect of this definition is exclusion" (236, original italics). This definition allows the characterization of established parties and newcomers with no established support base as ethnic parties. Both minority parties and majority nationalists can be classified as ethnic parties, if they appeal centrally and exclusively to an ethnic identity category. ${ }^{3}$ A distinctive feature of ethnic party competition is that social interaction takes place within intra-ethnic arenas, as well as within an inter-ethnic arena. In the intra-ethnic arena, parties appealing to the same ethnic identity category compete for votes. In the inter-ethnic arena, parties appealing to different ethnic identity categories interact with each other.

Bartolini ("Collusion, Competition and Democracy. Part I"; "Collusion, Competition and Democracy. Part II") seminally defined competition as one of four types of social interaction between autonomous actors. The other types are conflict, negotiation and cooperation. In conflictive and negotiative relationships, actors have different individual goals. In conflict, they perceive their goals as mutually exclusive and use direct or indirect force to inflict damage on each other when pursuing them. In negotiation, they perceive their goals as divergent, yet negotiable. Each actor controls a share of the prize and uses no force, but promises of future advantages and threats of disadvantages to negotiate. By contrast, Bartolini defines both competition and cooperation as types of interaction where actors aim at the same goal. In competition they aim at the same goal independently, without exchanging any of their available means, such as financial resources and information. In cooperation they share their resources to achieve the goal together since they perceive their interests as complementary, rather than as independent ("Collusion Part I" 439 440).

Yet, if "competition is a social relationship characterized by a system of interaction among consciously rival actors" that can "also be seen as the unintended outcome of such a system of interaction" (Bartolini "Collusion Part I" 438, emphasis added), it seems wise to treat competition not as a type of interaction in itself. Franzmann argued convincingly that competition as a system of interaction or, in his terms, an institution at the macro level, should be differentiated from types of interaction at the micro level. He suggests using the term 'contest' instead of competition to refer to interaction at the micro level and to reserve 'competition' for the situational logic at the macro level. Furthermore, parties may perceive their interests as complementary to the interests of ideologically similar parties, leading them to cooperate with the latter, while retaining contesting interaction with all others. As a consequence, both cooperation and contest form part of party competition. All parties cooperate at a very basic level when they accept common, democratic rules. In addition, parties can cooperate in electoral alliances and at the same time contest other parties that are not part of the alliance. If electoral institutions are disproportional, they reward larger parties and pre-electoral coalitions. This constitutes an incentive in particular for smaller parties to cooperate in pre-electoral 


\begin{tabular}{|c|c|c|}
\hline intraethnic arena a & interethnic arena & intraethnic arena b \\
\hline competition & no competition & competition \\
\hline$\rightleftarrows$ contest
\end{tabular}

Figure 1. Party competition in the perfectly segmented market.

coalitions (Golder). In sum: Competition as a structure at the macro level sets the rules for the specific interaction between parties at the micro level of strategic choice. Parties can choose whether to contest other parties or to cooperate with them. Following Franzmann, party competition can be defined as "an institution in which parties strategically cooperate or contest as political actors to gain political power" (320).

If the market is fully segmented along ethnic lines, none of the parties appeals to voters across the ethnic divide. Consequently, electoral competition means competition among parties seeking to represent voters from the same ethnic group. If e.g. Hungarian parties aim at the prize of Hungarian votes and Serbian parties at the prize of Serbian votes, their goals are not the same. At the same time, parties interact in the inter-ethnic arena, where moderates may opt to search for potential negotiation partners to advance their group specific claims. By contrast, if radicals prevail, conflict is the more likely outcome. The default assumption of conventional accounts of ethnic politics is such a fully segmented electoral market with stable voter party alignment: "In a perfectly plural society, an election is a segmental census" (Lijphart, "Consociational Theory: Problems and Prospects." 356) and "the communitarian aspect of ethnicity propels group members toward concentrated party loyalties" (Horowitz 294). Horowitz himself uses the term "segmented electoral market" (342) and argues that competition structures only interaction between parties competing for support among voters identifying with one and the same ethnic group, not between parties aiming at different ethnic groups (342). Figure 1 illustrates party competition in the ethnically perfectly segmented market.

None of the parties aim at voters across ethnic group divides. Parties aiming at voters from the same group may contest each other, but also at times cooperate (as is illustrated by $A_{1}$ and $A_{2}$ ), since both strategies are possible in competition. In the inter-ethnic arena, there is potential for conflict or negotiation, depending on whether radicals or moderates prevail, but no competition, since actors do not aim at the same goal. A contemporary example of party competition in an electoral market almost perfectly segmented along ethno-linguistic lines is Belgium where Flemish parties appeal only to Flemish-speaking voters and Walloon parties address only French-speaking voters.

From the perspective of the framework presented here outbidding will obtain if and only if the following conditions are satisfied: 
(1) In all intra-ethnic arenas, parties choose contest over cooperation;

(2) Parties contest each other by adopting more radical positions than their competitors.

Therefore, any explanation of ethnic outbidding has to address two interlinked questions: (1) Why did an ethnic party choose contest over cooperation? (2) Why did an ethnic party choose to contest opponents with a more radical position? Horowitz (346

349) himself was cautious enough to make clear that the outbidding model holds only if one sticks to intransigent voter preferences (rendering radical positions rewarding) and a system where only two parties contest each other (which makes electoral cooperation unnecessary). These conditions tend to be forgotten in later accounts of party competition in divided societies that turned outbidding from a theoretical model that holds under very specific assumptions into an almost universal expectation. It is easy to see why this is not satisfying. First, even if we grant that because moderate positions are already occupied a second party will outbid the original one, why should not a third ethnic party aim at more moderate voters, given that the most radical position is also already occupied?

Second, if parties choose to cooperate, there is no room for outbidding at all since condition 1 does not hold. During the 1990s for example, ethnic Hungarian parties in Romania, Slovakia and Ukraine "have tended to cooperate during elections to maximize their political power rather than seek to outbid each other" (Stroschein 66). This situation is highly desirable from the perspective of the power sharing model of ethnic politics. Like the outbidding model, the power sharing model starts from the assumption of a perfectly segmented electoral market and radical voters. Contrary to the outbidding model, the theory heavily relies on colluding, rather than competing elites. The question how "cohesive, political blocks" (Lijphart "Consociational Democracy" 221) of voters within each ethnic group decide on their legitimate representatives who form a "cartel of elites" (ibid.) in the first place is insufficiently addressed. Under the "working assumption of monolithic representation and deferential masses" (Caspersen 10), the situational logic posed by party competition within or across ethnic communities, and the factors driving ethnic parties' choice from a repertoire of mobilization strategies tend to be ignored. ${ }^{4}$ An unchallenged representational monopoly by one party within each ethnic community is seen as the ideal precondition to transform potentially conflictive interaction into peaceful negotiation in the inter-ethnic arena. Institutional power sharing induces actors to reach decisions through negotiation, in the consociational variant most importantly in a grand coalition that brings together elites of all relevant ethnic groups in a given society (Lijphart "Democracy in Plural Societies" 25 31). However, such an account neglects that competition structures parties' choice of strategy even if a single ethnic party has the representational monopoly since the monopolist strategically anticipates the entry of new competitors (Horowitz 309). If the monopolist is protecting against a potential radical newcomer, he may shift toward a more radical position than power sharing would predict on the basis of the hypothesized institutional incentives alone. The second problem of the power sharing account is that static institutions cannot explain variance in the strategies of one ethnic party over time or in the strategies of different parties within the same institutional context.

To summarize, the outbidding model assumes that there is intra-ethnic competition, with parties choosing contest over cooperation. Moderate parties that are ready to negotiate in the inter-ethnic arena will be challenged and replaced by more radical competitors, therefore conflict is likely to prevail in the long run. By contrast, the power sharing model relies on a representational monopoly, or permanent elite cooperation within the segments, 
and the cohesive, segmental elite's readiness to enter negotiations with elites from the other groups in society.

\section{Ethnic party competition beyond the segmented market}

An ethnically perfectly segmented market is, however, not the only possible constellation in democracies where ethnicity is politically mobilized. Unlike Horowitz (342) assumed, ethnic parties may function not only in fully segmented, but also in imperfectly segmented markets where some parties decide to operate across group divides. Furthermore, in the long run both the segmentation of the electoral market and the distribution of voter preferences on the ethnic dimension may be shaped by parties' strategic choices (Dunleavy and Ward). This leaves an important role for the strategic choices of ethnic party elites.

Whether voters will first demand more complex policy offers that cut across segmental needs, or whether parties begin to make offers to a wider electorate and thereby create their future, ethnically cross-cutting support base is difficult to disentangle empirically. To start my theoretical discussion somewhere, I take a fully segmented market as the starting point. From the perspective of parties' strategic choices, de-segmentation may begin with the decision by a party from either of the ethnic groups in the society to engage in "lateral bidding" (Zuber 4): the party widens its appeal beyond the ethnic group and includes a position on an ethnically cross-cutting dimension of party competition into its program (see also Chandra). ${ }^{5}$

In the case of an imperfectly segmented market where at least some parties make offers across the ethnic divide, types of social interaction are no longer differentiable by arena, but by individual interaction streams between parties. Whereas some parties appeal to voters across ethnic divides, others continue to appeal exclusively to "their" ethnic group. Examples of such imperfectly segmented markets include the case of competition for Hungarian votes in Vojvodina dealt with in the empirical section of this article but also party competition in Spain, where Catalan and Basque parties compete intra-ethnically for votes among "their" groups, yet also with the mainstream Spanish Socialist Workers' Party (PSOE). And whereas the Scottish National Party (SNP) appears largely unattractive to English voters, it still competes with the Labour party that has traditionally been very popular among Scottish voters. ${ }^{6}$

If all parties make offers across ethnic divides and voters vote without taking their ethnic identity into consideration, the market is no longer imperfectly segmented, but simply not ethnically segmented at all. Germany would be an example close to the ideal type of such an ethnically non-segmented electoral market. Despite the large share of Turkish migrants, no Turkish ethnic party has developed so far; parties generally appeal to voters irrespective of their ethnicity, and ethnic identity does not predict voting behavior. ${ }^{7}$

Therefore, the imperfectly segmented market with some ethnic parties and some ethnic voting is an intermediate type between the ideal types of perfect segmentation (only ethnic parties and ethnic voting) and perfect non-segmentation (no ethnic parties and no ethnic voting). Figure 2 presents the logic of party competition within.

In Figure 2, the two parties that engage in lateral bidding, $A_{\text {lat }}$ and $B_{\text {lat }}$, address an audience that cross-cuts the ethnic divide. As long as they also maintain a position regarding group specific interests on the ethnic dimension, they are now involved in intra-ethnic competition with their ethnic competitors (illustrated in figure two by the dotted lines), and in inter-ethnic competition with each other. By contrast, $A_{1}, A_{2}$, and $A_{3}$, and $B_{1}$ 


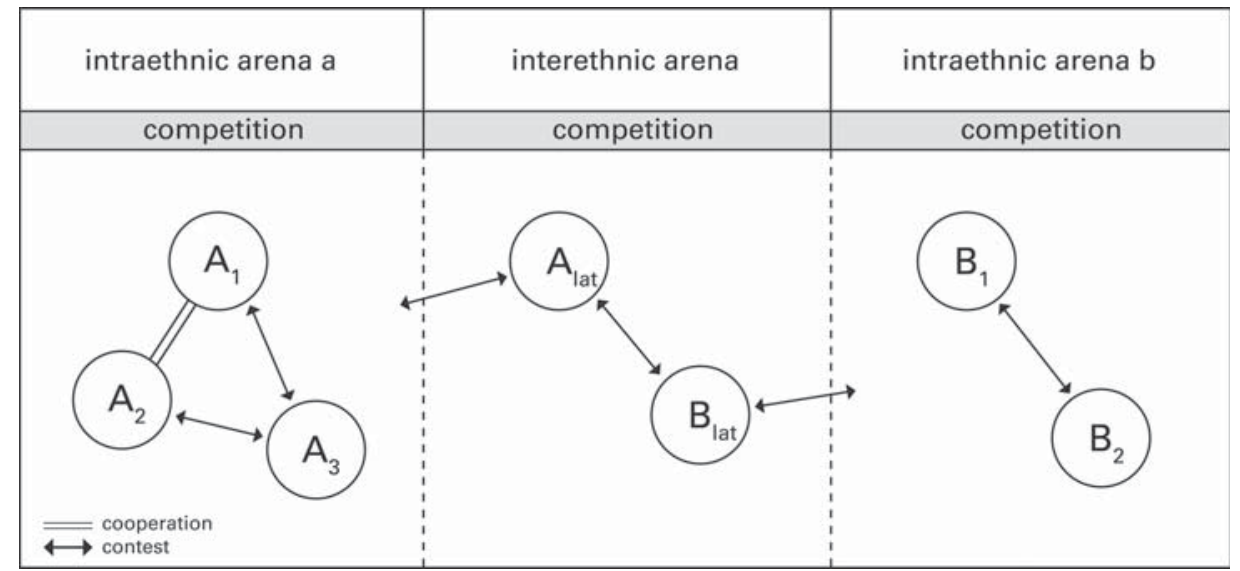

Figure 2. Party competition in the imperfectly segmented market.

and $\mathrm{B}_{2}$ remain within the logic of pure intra-ethnic competition. As before, cooperation and contest are possible strategies in competition.

It follows that in a theory of ethnic party competition beyond the segmented market, universal predictions for party behavior in competition have to be replaced by more specific predictions for parties competing only in the intra-ethnic arenas, as opposed to those involved in nested competition. Nested competition can now be defined as party competition where some, but not all parties appeal exclusively to ethnic identity categories and where competition between ethnic parties in one or several intra-ethnic arenas is nested within competition between parties launching lateral bids across ethnic divides in an inter-ethnic arena.

On pure logical grounds, types of social interaction between parties appealing to group A and parties appealing to group B can be discussed without reference to the size of the groups. Empirically, however, a majority-minority constellation is more common in European multinational democracies and is particularly favorable to nested competition since a large dominant group is likely to be represented by several state-wide parties already competing over a range of non-ethnic issues. I will therefore discuss the application of the model of nested competition to an ethnic minority group and ethnic minority parties, and an ethnic majority group and majority parties.

An ethnic minority party may decide to engage in lateral bidding and adopt a policy position on an ethnically cross-cutting dimension to become interesting also for voters who identify with the ethnic majority group. And even an already large majority party could still gain more votes if it was to attract also a significant share of minority voters. Unless the party is committed to a majority nationalist program, it can therefore be rational for a civic, state-wide party to enter competition for votes within a minority segment by presenting itself as a minority friendly choice, in particular when there is a competitive, fractionalized majority party system (Wilkinson). Since civic parties do not mobilize their voters on the basis of ethnic appeal to start with, this strategy is distinct from lateral bidding as defined above. Borrowing the term "predator" from Laver's (267) terminology of party strategies, the strategy of civic parties that approximate positions otherwise emphasized by ethnic minority parties can therefore be termed ethnic predating. Ethnic predating is neither exclusively directed at one ethnic category but rather at an overarching minority identity category nor the central part of a party program that 
still focuses predominantly on non-ethnic issues of state-wide party competition. ${ }^{8}$ Otherwise, the logic of nested competition still applies: A minority party that launches a lateral bid and adopts a policy position on an ethnically cross-cutting dimension of party competition and a civic party that decides to engage in ethnic predating may contest each other or cooperate, but they find themselves in a competitive situation because they are both aiming at votes across group divides. At the same time, other ethnic minority parties and majority nationalists may still perceive the market as fully segmented and direct their appeal exclusively directed at their ethnic fellows.

How does nested competition relate to the actual strategic positioning of the parties that contest each other and the likelihood of ethnic outbidding? Majority parties stand for more diverse policy options than the question of a minority group's status within the state. If a party makes an ethnic predator move and embraces some degree of special rights for minority groups as desirable, voting for this party may be attractive for a minority member, who sees minority rights as important, but also cares for other policy domains like e.g. social welfare and employment. ${ }^{9}$ We can safely assume that the predating party will occupy a rather moderate position with regard to the status of minorities within the state, since taking a radical, separatist stance would be irrational for a state-wide party. If the predator strategy successfully gains minority votes, this can exert a moderating pull on ethnic minority parties. They can now enlarge their voting base if they shift towards the moderate end, but remain slightly more radical than the predating majority party. Rather than just respond with a positional shift on the ethnic dimension, minority parties can of course also adopt the more complex strategy of lateral bidding. In the latter case, the party will be competing simultaneously with other ethnic parties in the intra-ethnic arena but also with majority predators on other dimensions of competition. Also in this case, the party should advocate a more moderate ethnic program to avoid deterring potential voters from the other ethnic group on the crosscutting dimension.

To conclude, nested competition can explain variance in the strategies of different ethnic parties within the same party system and strategic shifts over the course of a party's lifetime that remain unaccounted for by the outbidding model and the institutional-incentives perspective of the power sharing account. It does so by paying special attention to the fact that ethnic party elites take the behavior of their competitors into account when choosing their strategies. Even within the same institutional context, ethnic parties may attach varying levels of importance to the pay-offs in each electoral arena and differ in their judgment of who their main competitors are. Furthermore, in a majority-minority constellation, ethnic predating of large majority parties can be expected to provide incentives for ethnic minority parties to shift towards a more moderate position on the ethnic dimension of competition.

\section{Nested competition in Vojvodina}

To illustrate the theoretical concept of nested competition introduced to analyze ethnic party competition in the imperfectly segmented market, the following section presents a case study of nested competition for votes of the Hungarian national minority in Vojvodina, an ethnically diverse region in Northern Serbia. ${ }^{10}$ The case study discusses the national and regional level, leaving the local level for further research. ${ }^{11}$ Following an introduction to the case, the strategic considerations of party elites are analyzed in more detail. 


\section{Introduction to the case}

The Serbian state is asymmetrically decentralized. An intermediate level of government exists only within the autonomous province of Vojvodina (and formerly also the province of Kosovo and Metohija) that has a regional legislature and executive. The lowest level of government consists of 150 municipalities, 23 cities and the city of Belgrade ("Zakon o teritorijalnoj organizaciji”). Parties form electoral and governing coalitions not only at the national, but also at the provincial and the local level. The electoral system at the national level is list proportional representation (d'Hondt) with Serbia as a single, statewide electoral district and a 5\% threshold. For elections to the provincial assembly a mixed system applies. Out of the 120 members of the assembly of Vojvodina, 60 are elected by list proportional representation in a single, province-wide electoral district (5\% threshold); 60 are elected by majority vote in single-member electoral districts.

Parties of national minorities and electoral coalitions formed by parties of national minorities are exempt from the 5\% threshold both at the national level (Zakon o izmenama i dopunama zakona o izboru narodnih poslanika, article 13) and at the provincial level (Provincial assembly decision on the election of deputies, article 74). Fully proportional representation at the national level and the mixed system at the provincial level together with this eased condition for minority parties implies that competing on a pure minority list or even as a single minority party can be rewarding in terms of office gains in particular for minority parties aiming at larger minorities, such as ethnic Hungarians. With a share of $3.91 \%$ of the total population and $14.28 \%$ of the population in the autonomous province of Vojvodina (Republički zavod za statistiku), the Hungarian minority is Serbia's largest national minority.

Both at the national and the regional level, the Serbian arena of competition used to be predominantly structured by competition between the nationalist parties on the one, and the west-oriented, civic parties on the other side. The nationalist end thereby largely overlaps with the traditionalist, the civic with the modernist end of a traditionalist-modernist cleavage (Orlović 407). The Democratic Party (Demokratska stranka, DS), G17 plus, the Liberal Democratic Party (Liberalno-demokratska partija, LDP), and the regionalist League of Vojvodina Social Democrats (Liga socijaldemokrata Vojvodine, LSV) are all located on the civic end of the spectrum and can therefore potentially play the role of ethnic predators.

The Serbian Radical Party (Srpska radikalna stranka, SRS), the Democratic Party of Serbia (Demokratska stranka Srbije, DSS), and the Socialist Party of Serbia (Socijalistička partija Srbije, SPS) used to be the key Serbian nationalist players. SRS was at the same time the most radical and the most successful competitor for nationalist votes in the Serbian intra-ethnic arena, especially in ethnically mixed areas such as Vojvodina where nationalist issues are particularly salient among Serbian voters and where there is strong intra-ethnic competition between Serbian majority nationalists (Bochsler 112). In September 2008, however, Tomislav Nikolić then leader of the parliamentary group of the SRS gathered some SRS members and founded a new parliamentary faction ("Nikolić oformio poslanički klub."). By October 2008, this faction had developed into a new party, the Serbian Progressive Party (Srpska napredna stranka, SNS). In stark contrast to SRS, SNS is in favor of European integration and has succeeded in becoming the strongest competitor to DS, whereas support for SRS has dropped considerably ("Birači se dvoume između DS i SNS.”).

The electoral market in Serbia has been described as heavily segmented, dominated by minority parties who "control virtually all votes in their subgroups" (Todosijević 522). 
However, this is no longer the case as far as the Hungarian minority in Vojvodina is concerned. The choice set of voters in Vojvodina who declare themselves as Hungarian extends beyond Hungarian parties and includes both a state-wide party (DS) and a regionalist party without ethnic appeal (LSV). The Democratic Alliance of Vojvodina Hungarians (in Hungarian: Vajdasági Magyar Szövetség, in Serbian: Savez vojvođanskih Mađara, SVM) is the dominant Hungarian minority party. DS on the other hand is playing the role of an ethnic predator and has been very successful in gaining votes of members of national minorities and in particular of the Hungarian minority since 2007 (Tóth, 11 May 2010). Hungarian voter preferences are evident from a survey of late autumn 2009, where $35 \%$ of Hungarians in Vojvodina declared their preference for SVM, $22.3 \%$ for DS, $8.3 \%$ for LSV, 3.4\% for DZVM, another Hungarian party, and $20.9 \%$ declared they would not vote (SCAN 10). ${ }^{12}$

In addition to SVM, four ethnic parties participate in intra-ethnic Hungarian competition. These parties can be differentiated mainly through their positions on the ethnic Hungarian dimension of competition that is defined by the extent of autonomy advocated by Hungarian parties. The Democratic Community of Hungarians in Vojvodina (in Hungarian: Vajdasági Magyarok Demokratikus Közössége, in Serbian: Demokratska zajednica vojvođanskih Mađara, DZVM) is the oldest of these parties. The Democratic Party of Vojvodina Hungarians (in Hungarian: Vajdasági Magyar Demokrata Párt, in Serbian: Demokratska stranka vojvođanskih Mađara, DSVM), a splinter from DZVM under the leadership of András Ágoston, does not demand territorial autonomy, but a combination of personal and cultural autonomy (Ágoston, 7 June 2010). DZVM, the Civic Union of Hungarians (in Hungarian: Magyar Polgári Szövetség, in Serbian: Građanski savez Madara, GSM) and a recent newcomer, the Movement of Hungarian Hope (in Hungarian: Magyar Remény Mozgalom, in Serbian: Pokret mađarske nade, PMN) are in favor of cultural and personal autonomy, but additionally demand ethnoterritorial autonomy for the Hungarian dominated municipalities in Northern Bačka, the Northern part of Vojvodina that borders Hungary (Rác Szabó, 3 June 2010; Setyerov, 3 June 2010).

SVM contested the national and provincial parliamentary elections of May 2008 in an electoral alliance with DZVM and DSVM, the "Hungarian Coalition". The coalition won four seats in the national parliament, and nine seats in the parliament of Vojvodina. For the national and provincial elections of May 2008, the Hungarian coalition presented a shared concept of autonomy that included also an ethno-territorial component: "The aim of the Hungarian coalition is the formation of an autonomous region of Hungarians with its seat in Subotica, which apart from the city of Subotica would include the municipalities of Ada, Čoka, Bačka Topola, Bečej, Kanjiža, Mali Iđoš, Novi Kneževac and Senta" ("Zajednički koncept autonomije" Part II).

By the time of the author's field research between April and June 2010, the Hungarian coalition had, however, fallen apart, leaving the parties free to contest each other and make different offers to their voters. And indeed, in contrast to the four Hungarian parties that limit their appeals exclusively to Hungarians, SVM had begun to widen its appeal aiming also at a regional, non-ethnically defined electorate. According to a member of the steering committee, the party now seeks to defend the regional interests of the autonomous province of Vojvodina (Maglai 6 June 2010) and party leader Istvan Pastor openly describes the party as a regional party that caters for regional interests ("Pastor: LSV birače doživljava kao budale"). Hungarians constitute a minority also within the region of Vojvodina. Defending or seeking to increase Vojvodina autonomy therefore exceeds the limits of narrowly defined competition on the ethnic dimension of group specific Hungarian interests 


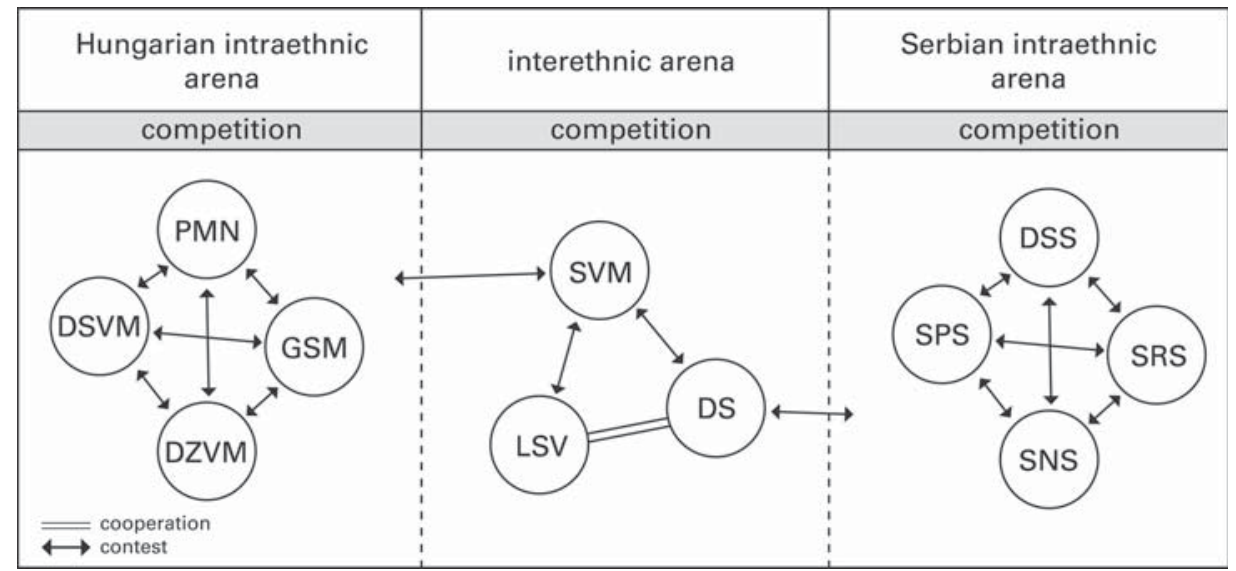

Figure 3. Party competition Vojvodina

and brings together voters from different ethnic groups that are in favor of devolving further competencies to the regional institutions. Figure 3 graphically summarizes this constellation of nested competition for Hungarian votes. According to the perceptions of elite respondents at the time of field research, contest dominated the relations between DS and SVM, cooperation the relationship between DS and LSV. The symbols in Figure 3 were chosen accordingly, even though formally both LSV and SVM formed part of the provincial governing coalition headed by DS.

\section{Nested competition and the strategic considerations of ethnic party elites}

In the 2008 elections to the national and the provincial parliament, the polarization between DS and SRS among Serbian voters was extremely high and the future of Serbia was on the tipping point between those in favor (DS and its allies) and those against (SRS) European integration (Maglai 6 June 2010). Hungarians voted in a pluridimensional political space, structured by the antagonism between pro and anti-European integration parties on the one hand and by the ethnic Hungarian dimension on the other hand. They traded the choice between voting for their favorite model of being represented as a minority group within the state against playing a role in determining the future path of the Serbian state. Ethnic Hungarian parties encountered the problem that many of their voters preferred to help tip the balance in favor of Serbia's EU integration over voting for one or the other model of Hungarian autonomy.

In this situation, DS could present itself as an optimal choice that combines a minorityfriendly stance with economic offers and a pro-European stance: "DS literally gained more votes of Hungarians than SVM but what is the reason? Because we as a large and statewide party not just regional and we are naturally also a civic party besides the fact that we have ensured the conditions for national minorities to preserve their identity, also offer something else, we go one step further, to provide the so called conditions for a better life, that means economic security and social and health security" (Tóth, 11 May 2011). This shows that rather than providing vote payoffs in the intra-ethnic arena by default, a one dimensional ethnic program can make ethnic party incumbents highly vulnerable as soon as competition in the majority arena becomes polarized with regard to other topics that are of interest to citizens. 
SVM responded to the predator challenge and now tries to emphasize regional politics. Representing the interests of Vojvodina could bring SVM into the position of a more influential political force, drawing on a distinct Vojvodina identity that exceeds the narrow boundaries of Hungarian ethnicity. At least in 2009, however, voters still most clearly identified LSV with the topic of Vojvodina autonomy and SVM with the representation of Hungarian interests. $63 \%$ of LSV voters stated that they voted for the party because "they are in favor of Vojvodina, of autonomy and of everything linked to this topic", whereas only 3.9\% of SVM voters gave this reason for voting for SVM. By contrast, $46.1 \%$ of SVM voters declared to have chosen SVM because it is a Hungarian party (SCAN 13). However, the fact that those who voted for SVM in the past had mainly ethnic reasons to do so does not contradict attempts of SVM elites to gain new voters with a regionalist position in the future.

With a position on the ethnic dimension as well as on the dimension of Vojvodina autonomy, SVM has entered nested competition. The dimension of Vojvodina autonomy is structured by the juxtaposition of SRS, that is completely opposed to Vojvodina autonomy, DSS that seeks to subsume the question of Vojvodina under a concept of symmetric decentralization, DS that favors Serbia's asymmetrical decentralization with a special autonomy status for Vojvodina and LSV as the long-standing regionalist defender of comprehensive autonomy for the province (Komšić 394-403). Together with Kosovo and Metohija, Vojvodina used to enjoy the special status of an autonomous province within the Socialist Republic of Serbia, one of the constituent units of Yugoslavia. In November 2009, Vojvodina received an autonomy statute ("Zakon o utvrđivanju nadležnosti”) that reinstalled some of the powers Vojvodina was deprived of by Milošević in 1989. ${ }^{13}$ However, the financial details of regional autonomy were still disputed after the statute was granted.

When the Serbian parliament was to decide on the national budget at the end of 2009, the four MPs of SVM that form part of the current DS-led governing coalition both at the national level and at the level of the Vojvodina executive refused to vote for the budget, on their account because it did not earmark the constitutionally prescribed share of $7 \%$ of the total budget for the province. SVM elites emphasized that with this move, they presented themselves as the last remaining defenders of Vojvodina autonomy (Bús, 13 May 2010). Relatedly, they were eager to portray LSV, the traditional regionalist player as losing its profile. LSV cooperated firmly with DS at the national level of politics and contested the 2008 elections to the Serbian parliament as part of an electoral alliance led by DS. On the account of SVM MP Elvira Kovács, at least at the national level of politics, where regional autonomy has to be defended against the interests of the central state, their voice has been getting lost in the wider club of DS MPs since then (Kovács, 12 May 2010). SVM's vote against the national budget at the end of 2009 can be seen as a clear signal to voters that SVM seeks to defend Vojvodina autonomy even against DS, their coalition partner in the national and provincial government. ${ }^{14}$

Given that Vojvodina Hungarians are also mostly in favor of Vojvodina autonomy, this is not a very risky strategy, since it can gain the party more voters that share the regional, though not the ethnic Hungarian identity category, while not necessarily deterring Hungarians from voting for the party either. $43.2 \%$ of Hungarians in Vojvodina, compared to only 13.5\% of Serbs in Vojvodina want to return the autonomy status of 1974 to the province, and $12.6 \%$ of Hungarians compared to $1.3 \%$ of Serbs would like to see Vojvodina as an independent state (SCAN 18).

When adopting issues that have the potential to appeal to an electorate beyond the group ethnic parties enter the complex grounds of nested competition. The electorally 
successful predator appeal of DS to Hungarians in Vojvodina has thus set incentives for SVM to emphasize a cleavage that incorporates traditional voters (Hungarians in Serbia live predominantly in Vojvodina) but that at the same time differs from the ethnically defined territorial autonomy concept advocated by most of the other Hungarian parties. Were they only competing with other Hungarian parties with exclusive appeal focused on Hungarian issues, they might stick to a more narrowly ethnic program and try to sell themselves as the most authentic representatives of the Hungarian people. Yet, these parties are not seen as competitors at all: "We have four or five Hungarian parties in Vojvodina, but during the last ten years it turned out that they are no competitors for SVM [...] for us the main competitor in all elections unfortunately over the last ten years is DS, and on the provincial level LSV" (Bús, 13 May 2010). At the same time, DS as an ethnic predator cannot go to the extreme of supporting ethno-territorial autonomy for Hungarians, a concept of territorial state organization that all major Serbian parties have always opposed (Komšić 393). Even an ethnic Hungarian member of the DS elite refers to the ethno-territorial autonomy concept advertised by DZVM, PMN and GSM as "ghettoization" (Tóth, 11 May 2011).

Importantly, SVM has not only widened its appeal but has also shifted its position on the ethnic Hungarian dimension of competition that is defined by the degree of autonomy advocated by Hungarian parties. Whereas the Hungarian coalition (including SVM) defended territorial autonomy during the 2008 electoral campaign, SVM elites stated in 2010 that they now defend cultural autonomy for the Hungarian national minority. SVM member of parliament Elvira Kovács emphasized that SVM played a decisive role in drafting and getting the government to pass the law on national minority councils in August 2009 and that the party's concept of autonomy can now be fully realized through these cultural institutions (Kovács 12 May 2010, for more details on this shift in SVM's strategy, see Zuber 10 11).

The fact that SVM defends Vojvodina autonomy and even voted against the budget remained obscure and incomprehensible from the perspective of its competitors in the intra-ethnic Hungarian arena, who think only in terms of competition on the ethnic dimension defined by Hungarian interests. From their perspective, Vojvodina autonomy constitutes a Serbian topic that should not concern Hungarians. Elites of DSVM and PMN maintained that neither regional autonomy nor European integration were adequate topics for a minority party that should above all be concerned with the status of Hungarians in Vojvodina and Serbia and not with the wider politics of Serbia, or the status of the province (Ágoston, 7 June 2010; Setyerov, 3 June 2010). The vice president of DZVM wondered why a Hungarian party would use its strategic potential within the governing coalition to defend the interests of Vojvodina, when it could use its position much better to defend Hungarian interests: "They [referring to SVM, author's note] made this fuss about the budget when there was no need instead of making a fuss when Hungarian interests were at stake" (Horváth Ódry, 10 June 2010). A moderate position on the ethnic dimension appears as an irrational choice from the perspective of the intra-ethnic game, given that it might open space for outbidding parties on the radical end. By contrast, from the perspective of nested competition, where SVM competes principally with a Serbian majority party (DS), that cooperated closely with a regionalist party (LSV) for the 2008 national elections, the "fuss" of a strategy aimed at regional, not just Hungarian identity categories seems rational. SVM does not only have to take potential radical outbidding in the intra-ethnic arena, but also majority predating in the inter-ethnic arena into account. ${ }^{15}$ 
To summarize, SVM, the most successful Hungarian party hardly sees itself as competing any longer with Hungarian parties, but with the regionalist LSV and the civic, state-wide DS. By contrast, the other Hungarian parties perceive the electoral market as segmented and see only the other Hungarian parties as their competitors or potential allies. In nested competition, different types of social interaction prevail between parties depending on whether they are playing the full nested game or whether they are only involved in intra-ethnic competition and this affects their strategic choices between exclusive and non-exclusive appeal and between different policy positions on the ethnic dimension of competition. SVM, the ethnic party involved in nested competition is at the same time the party that recently shifted towards a more moderate position on the dimension of Hungarian autonomy.

\section{Conclusion}

With the ethno-nationally motivated territorialization of politics in many Western European states and the democratization of Eastern European countries that have a legacy of mobilized ethnicity, parties that appeal to ethnic identity categories have become more frequent players in democratic politics. This article has presented an account that avoids subsuming their behavior in party competition under overly simplistic assumptions and that provides scholars with a new set of theoretical concepts that can capture ethnic party competition not only within, but also beyond the segmented market. The aim was thereby not to disqualify conventional theories of ethnic politics, but to show that their empirical applicability to party competition in contemporary democracies where ethnicity is mobilized is limited. In particular, the prominent outbidding model is not a theory of ethnic party competition per se, but a theory of intra-ethnic competition in a fully segmented market where a radical ethnic voter distribution precludes electoral rewards for moderate ethnic parties. Such cases do exist, and here the outbidding model has its strength. By contrast, a more general theory of ethnic party competition should seek to apply also to cases of nested competition in imperfectly segmented markets. The key characteristic of all cases that fall under the theory is that at least some parties appeal exclusively to an ethnic identity category and position themselves on an ethnic dimension of competition. Party competition in a fully segmented market, where all parties appeal exclusively to an ethnic identity category is then simply a special instance of party competition involving appeals to ethnic identity categories more generally.

I have argued in the theoretical section that a structure of nested competition holds incentives for ethnic parties to moderate their positions and can therefore reduce the likelihood of ethnic outbidding. In particular if large mainstream parties which accommodate the demands of ethnic minorities are electorally successful, ethnic minority parties gain a signal that votes can be gained on the moderate end of the spectrum of minority demands. If ethnic parties begin to see mainstream parties as their primary competitors for votes, such as in the case of the Hungarian SVM, ethnic outbidding is unlikely to appear as an attractive strategy to regain voters willing to vote for a Serbian mainstream party. SVM elites have not only decided to moderate the party's ethnic stance, but also to widen its portfolio, calling for the extension of regional competencies and advocating regional economic policies, centre-periphery issues that cross-cut the ethnic divide. The illustrative case study of nested competition for Hungarian votes in Serbia has thus provided first evidence for the fact that ethnic party elites indeed differ in their assessment of the importance attached to the intra- and the inter-ethnic arena and choose their strategies accordingly. Systematic comparative research is now needed to test whether the nested 
competition explanation for the absence of outbidding in ethnic party competition can be generalized.

The case analyzed here was drawn from Eastern Europe, but instances of nested competition can be found also in Western Europe. A prominent case is Spain, where in particular the state-wide PSOE has been playing the role of an ethnic predator in the autonomous communities, joining ethno-nationalist parties in their demands for increased autonomy. In the case of the autonomous community of Catalonia, the regional branch of the PSOE has even developed into a formally separate party, the Catalan Socialist Party (PSC) (Hopkin 233). By contrast, the contemporary, confederal Belgian party system lacks state-wide parties and could be described as perfectly segmented. The two green parties, "Groen!" and "Ecolo", however, publish joint electoral manifestos and aim to de-segment the ethno-linguistically divided electoral market. Further research should now analyze party strategies in these and other contexts where ethnic issues play a role in party competition and see whether systematic links between parties' strategic choices between moderate and radical positions, the degree of segmentation, and the prevailing types of social interaction within and across arenas can be established.

\section{Acknowledgements}

A previous version of this article was presented at the $16^{\text {th }}$ Annual ASN Convention, New York, 1618 April 2011. I would like to thank Nicole Bolleyer, Simon Franzmann, Ulrich Glassmann, Oleh Protsyk, Saskia Ruth, Jan Sauermann, Edina Szöcsik and Gregor Zons and several anonymous referees for very helpful comments and Woldai Wagner for assistance with designing the figures. Out of the numerous people who supported my field research in Serbia, Lidija Prokić and Žaklina Veselinović deserve special thanks for putting me into contact with a number of my interview partners. Milka Puzigaća kindly provided the SCAN data on Hungarian voter preferences. I also thank all my interview partners for their time. Field research in Serbia was financially supported by the German Academic Exchange Service (DAAD).

\section{Notes}

1. Following Birnir, "an ethnic group is defined by members of the group who consider themselves ethnically distinct from other groups in society" and where "this identification centers on a characteristic that is difficult to suppress, such as language, location, or race" (24).

2. Tsebelis (159 186) already discusses consociationalism as one application of his theory of nested games. Segmental electoral arenas are nested within the parliamentary arena where elites of the segments negotiate. The key difference between my account of nested competition and consociationalism, even when seen as a nested game, is that in nested competition the inter ethnic arena is itself an arena for electoral competition and incentives for moderation arise from the situation of nested competition, not merely from power sharing institutions.

3. A discussion of the question why some parties choose to mobilize ethnic over other social cat egories in the first place is beyond the scope of this paper (for an instrumental explanation, see Posner). I start from a context where at least some parties already appeal to ethnic identity cat egories in party competition.

4. This is not meant to imply that power sharing institutions are irrelevant; quite the opposite, they play a crucial role in establishing peace arrangements acceptable to all parties after inter ethnic conflict (Walter). My more modest point is that the power sharing perspective does not provide adequate concepts to understand party competition within and across ethnic groups.

5. Which dimensions are ethnically cross cutting depends on the given context and can only be settled empirically. I therefore discuss the actual policy content of lateral bidding only in the empirical part. 
6. Since all these examples are at the same time instances of multi level competition, the theoreti cal relationship between nested competition and multi level competition calls for clarification. Multi level competition is neither sufficient nor necessary for nested competition. We can think of nested competition without multi level competition if parties compete within and across groups but only at one territorial level and of multi level competition in purely segmented markets where parties compete at various territorial levels, but not across groups (e.g. in Belgium). Empirically, nested competition covaries with multi level competition in particular in multinational European settings where ethnic identity categories are often territorially based and where the creation of regional assemblies was driven by the demands of ethno nationalist parties. I am indebted to an anonymous referee for forcing me to clarify this point.

7. Strictly speaking, there are local exceptions to this picture of the non segmented German elec toral market, such as the party of the Danish minority in Schleswig and the Frisian minority in Nordfriesland, the "Südschleswigscher Wählerverband" and the Muslim BIG party (Bündnis für Innovation \& Gerechtigkeit) that was founded in 2010 but has so far failed to gain any mandates.

8. Hopkin describes this phenomenon for ethno regionalist 'predators' (without using this term) in Spain, Britain and Italy. However, he is more interested in the intra party dynamics between regional branches and central office than in patterns of interaction between the parties approxi mating regionalist positions and the original ethno regionalist parties. The strategy can be related to Meguid's (Meguid) theory of party competition between mainstream and niche parties: If niche parties (such as ethnic minority parties) enter the electoral arena as advocates of a niche issue (such as ethnic minority interests), mainstream parties have three strategic options: They can dismiss the new issue, trying to keep its salience low, or they can themselves adopt a position on the new issue. If they adopt a position, they can either choose an adversarial position or an accommodative position. Ethnic predating can be seen as an instance of Meguid's accommodative strategy with regard to ethnic minority issues. However, Meguid's account is focused on mainstream parties' strategic choices and does not provide the theoretical tools to model competition within the niche (intra ethnic competition) and niche parties' own strategic responses to mainstream parties.

9. One interview partner from DZVM, an ethnic Hungarian party in Serbia, tellingly imagined what might go on in the mind of a young Hungarian when considering whether to vote for DZVM or for the governing Democratic Party: "Who the hell cares that I can talk Hungarian if I do not have anything to eat?" (Elvegyi, 10 June 2010).

10. The case study draws on insights the author gained during field research in Serbia between 15 April and 15 June 2010. All interviews were conducted in Serbian; translations to English are the author's. The guideline for the semi structured interviews is available upon request.

11. Triangulating the answers from SVM interview partners active at the national (Kovács) and the provincial level (Bús, Maglai) I found their answers to converge, pointing to a unified strategy of the party at least across regional and national level. On the basis of the evidence collected I cannot exclude that SVM maintains a more radical position at the municipal level. Thanks to an anonymous referee for pointing me to this possibility.

12. Public opinion data was provided to the author in the form of a PDF document summarizing aggregate results of a survey conducted by the commercial, Novi Sad based public opinion research institute "SCAN Agency" during the end of October and the beginning of November 2009. The data was provided by Milka Puzigaća, director of SCAN Agency. The full sample size of the survey was 1480 respondents, out of which 206 declared themselves as Hungarians. The other Hungarian parties besides SVM and DZVM were not mentioned in the survey.

13. After the constitutional amendment of 1974 that recognized Vojvodina and Kosovo as constitu tive elements of the Yugoslav federation, the provinces enjoyed far reaching autonomy, similar to the status of the actual constituent republics of Yugoslavia.

14. Following the 2008 elections, the governing coalition at the national level was constituted by the DS led electoral coalition "For a European Serbia", the electoral coalition of SPS PUPS JS, the "Hungarian coalition", and the "Bosniak list for a European Sandžak". It held a majority of 128 out of 250 seats. (Orlović 182 183). The governing coalition at the provincial level was con stituted by DS, G17 plus, the "Hungarian coalition", LSV and SPS that together held 91 out of 120 seats ("Pajtić obećao evropsku Vojvodinu").

15. A choice that appears suboptimal from the perspective of the game in one arena, but rational once the wider game and all arenas and all players are taken into account is typical for nested games (Tsebelis). 


\section{References}

Ágoston, András, Leader of DSVM, personal interview. Temerin: 7 Jun. 2010. Print.

Andeweg, Rudy B. "Consociational Democracy." Annual Review of Political Science 3.1 (2000): 509 536. Print.

Bartolini, Stefano. "Collusion, Competition and Democracy. Part I." Journal of Theoretical Politics 11.4 (1999): 435 470. Print.

Bartolini, Stefano. "Collusion, Competition and Democracy. Part II." Journal of Theoretical Politics 12.1 (2000): 33 65. Print.

"Birači se dvoume između DS i SNS." Danas. 22 April 2010. Print.

Birnir, Jóhanna Kristín. Ethnicity and Electoral Politics. Cambridge: Cambridge UP, 2009. Print.

Bochsler, Daniel. "The party system of Serbia". Party Politics in the Western Balkans. Eds. Vera Stojarová and Peter Emerson. London and New York: Routledge, 2010. 99 118. Print.

Bochsler, Daniel, and Edina Szöcsik. "Where dissident Hungarian minority leaders look for success: Building bridges in Slovakia, or demarcating a Hungarian motherland in Romania?" Paper presented at the ECPR Joint Sessions, Münster, 2227 March 2010.

Bús, Ottó, Member of the Vojvodina parliament for SVM, member of SVM presidency, personal interview. Novi Sad: 13 May 2010.

Caspersen, Nina. Contested Nationalism. Serb Elite Rivalry in Croatia and Bosnia in the 1990s. Oxford: Berghahn Books, 2010. Print.

Chandra, Kanchan. "Ethnic Parties and Democratic Stability." Perspectives on Politics 3.2 (2005): 235 252. Print.

Coakley, John. "Ethnic Competition and the Logic of Party System Transformation." European Journal of Political Research 47.6 (2008): 766 793. Print.

Downs, Anthony. "An Economic Theory of Political Action in a Democracy." The Journal of Political Economy 65.2 (1957): 135 150. Print.

Dunleavy, Patrick, and Hugh Ward. "Exogenous Voter Preferences and Parties with State Power: Some Internal Problems of Economic Theories of Party Competition." British Journal of Political Science 11.3 (1981): 351 380. Print.

Elvegyi, Ákos, Member of DZVM presidency, personal interview. Sombor: 10 Jun. 2010.

Franzmann, Simon. T. "Competition, Contest, and Cooperation: The Analytic Framework of the Issue Market." Journal of Theoretical Politics 23.3 (2011): 317 343. Print.

Golder, Sona N. "Pre Electoral Coalition Formation in Parliamentary Democracies." British Journal of Political Science 36.2 (2006): 193 212. Print.

Gormley Heenan, Cathy, and Roger Macginty. "Ethnic Outbidding and Party Modernization: Understanding the Democratic Unionist Party's Electoral Success in the Post Agreement Environment." Ethnopolitics 7.1 (2008): 43 61. Print.

Hale, Henry E. The Foundations of Ethnic Politics. Separatism of States and Nations in Eurasia and the World. Cambridge: Cambridge UP, 2008. Print.

Hopkin, Jonathan. "Political Decentralization, Electoral Change and Party Organizational Adaptation: A Framework for Analysis." European Urban and Regional Studies 10.3 (2003): 227 237. Print.

Horowitz, Donald L. Ethnic Groups in Conflict. Berkeley: U of California P, 1985. Print.

Horváth Ódry, Márta, Vice president of DZVM, personal interview. Sombor: 10 Jun. 2010.

Komšić, Jovan. Dileme demokratske nacije i autonomije. Ogledi o političkoj tranziciji u Srbiji. Beograd: Službeni glasnik 2006. Print.

Kovács, Elvira, Member of Serbian Parliament for SVM, member of SVM presidency, personal interview. Belgrade: 12 May 2010.

Laver, Michael. "Policy and the Dynamics of Political Competition." American Political Science Review 99.2 (2005): 263 281. Print.

Lijphart, Arend. "Consociational Democracy." World Politics 21.2 (1969): 207 225. Print.

Lijphart, Arend. Democracy in Plural Societies. A Comparative Exploration. New Haven: Yale UP, 1977. Print.

Lijphart, Arend. "Consociational Theory: Problems and Prospects. A Reply." Comparative Politics 13.3 (1981): 355 360. Print.

Maglai, Jenô, Member of SVM presidency, personal interview. Subotica: 6 Jun. 2010.

Meguid, Bonnie M. Party Competition between Unequals. Strategies and Electoral Fortunes in Western Europe. Cambridge: Cambridge UP, 2008. Print. 
Mitchell, Paul, Geoffrey Evans, and Brendan O'Leary. "Extremist Outbidding in Ethnic Party Systems is not inevitable: Tribune Parties in Northern Ireland." Political Studies 57.2 (2009): 397 421. Print.

"Nikolić oformio poslanički klub." B92 online, 8 Sep. 2008. Web. 9 Feb. 2011.

Norris, Pippa. Driving Democracy: Do Power Sharing Institutions Work? New York: Cambridge UP, 2008. Print.

Orlović, Slaviša. Politički život Srbije: Između partokratije i demokratije. Belgrade: Službeni glasnik, 2008. Print.

"Pajtić obećao evropsku Vojvodinu." Blic online, 17 Jul. 2008. Web. 27 October 2011.

"Pastor: LSV birače doživljava kao budale." Radio 021 online, 13 Sep. 2011. Web. 14 Oct. 2011.

Posner, Daniel N. "The Political Salience of Cultural Difference: Why Chewas and Tumbukas are Allies in Zambia and Adversaries in Malawi." American Political Science Review 98.4 (2004): 529 545. Print.

Protsyk, Oleh, and Stela Garaz. "Politicization of Ethnicity in Party Manifestos." Party Politics. Published online before print on 10 Jun. 2011, doi: 10.1177/1354068811398058. Web. 3 Nov. 2011.

Provincial assembly decision on the election of deputies of the autonomous province of Vojvodina, Official journal of APV 12/2004, 20/2008, 5/2009, 18/2009, 23/2010 i 1/2012. Web. 19 Mar. 2012. <http://www.skupstinavojvodine.gov.rs/?s=aktAPV010\&j=EN>.

Rabushka, Alvin, and Kenneth. A. Shepsle. Politics in Plural Societies: A Theory of Democratic Instability. Columbus, Ohio: Charles E. Merrill, 1972. Print.

Rác Szabó, László, Leader of GSM, personal interview. Subotica: 3 Jun. 2010.

Republički zavod za statistiku (2003) "Popis stanovnistva, domačinstava i stanova u 2002" [Census of population households and housing 2002]. Web. 1 Jul. 2010. < http://webrzs.stat.gov.rs/ axd/Zip/VJN3.pdf $>$.

SCAN Agencija za istraživanja i razvoj d.o.o. (2009). Istraživanje javnog mnenja, Vojvodina oktobar 2009. Stranačke preferencije. Stavovi o nadležnostima Vojovodine. [SCAN Agency for research and development. Public opinion research. Vojvodina October 2009. Party Preferences. Stands on the competences of Vojvodina] Novi Sad, November 2009. Print.

Setyerov, Zorán. Vice president of PMN, personal interview. Subotica: 3 Jun. 2010.

Sisk, Timothy D. Power Sharing and International Mediation in Ethnic Conflicts. Washington DC: United States Institute of Peace, 1996. Print.

Stroschein, Sherrill. "Measuring Ethnic Party Success in Romania, Slovakia, and Ukraine." Problems of Post Communism 48.4 (2001): 59 69. Print.

Todosijević, Bojan. "Serbia." The Handbook of Political Change in Eastern Europe. Eds. Sten Berglund, Joakim Ekman, and Frank H. Aarebrot. Cheltenham: Edward Elgar, 2004. 493 543. Print.

Tóth, Tamás, Member of the Serbian parliament for DS, member of DS central and provincial steer ing committee, personal interview. Belgrade: 11 May 2010.

Tsebelis, George. Nested Games. Rational Choice in Comparative Politics. Berkeley and Los Angeles: U of California P, 1990. Print.

Walter, Barbara F. Committing to Peace. The Successful Settlement of Civil Wars. Princeton New Jersey: Princeton UP, 2002. Print.

Wilkinson, Steven I. Votes and Violence. Electoral Competition and Ethnic Riots in India. Cambridge: Cambridge UP, 2004. Print.

"Zajednički koncept autonomije stranaka Vojvođanskih Mađara." [Common Autonomy Concept of the Parties of Vojvodina Hungarians]. Official website of SVM. Web. 12 Aug. 2010.

"Zakon o izmenama i dopunama Zakona o izboru narodnih poslanika." [Law on the changes and additions to the Law on the election of members of parliament]. Web. 19 March 2012. < http://www. parlament.gov.rs/upload/archive/files/lat/pdf/zakoni/2004/pdf 00433304 Lat.zip>.

"Zakon o utvrđivanju nadležnosti autonomne pokrajine Vojvodine." [Law establishing the compe tences of the autonomous province of Vojvodina]. Web. 2 Mar. $2010<$ http://www. parlament.gov.rs/content/cir/akta/akta detalji.asp?Id=700\&t=Z\#>.

"Zakon o teritorijalnoj organizaciji republike Srbije, 29.12.2007." [Law on the territorial organiz ation of the Republic of Serbia], Službeni glasnik: 129 07. Web. 30 May 2010. <http:// www.parlament.gov.rs/content/lat/akta/akta detalji.asp?Id=466\&t=Z\#>.

Zuber, Christina Isabel. Beyond Outbidding. Ethnic Party Strategies in Serbia, Party Politics, published online before print on 25 Jul. 2011. DOI: 10.1177/1354068811410368. Web. 3 Nov. 2011. 